\title{
Namurian (Upper Carboniferous) shallow marine and turbiditic sediments, Clare, western Ireland
}

\author{
Masaaki Tateishi (Department of Geology, Niigata University)
}

The coastline of Clare, western Ireland, provides excellent sections of Carboniferous clastic sediments that should be one of the most spectacular outcrops in Western Europe. In 1990 I visited the coast in a field trip of the 13rd International Sedimentological Congress in Notthingham, U.K., which was led by T. Elliot and others.

On the Cover: HÇS sandstones of the Tullig Cyclothem, Central Clare Group, at northwest of Doonbeg. At this outcrop the trip leaders stated that this should belong to a mouth-bar complex, which caused a controversy.

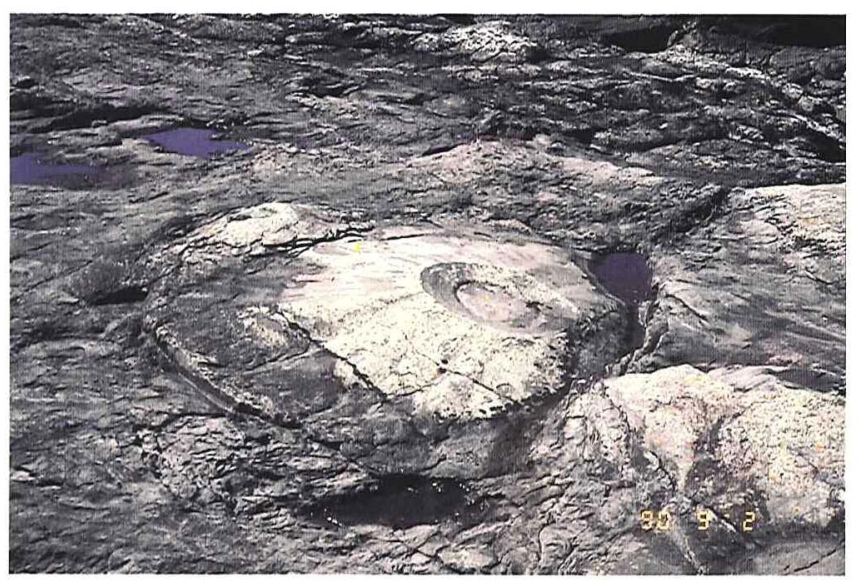

Fig. 1: "Fine-sand volcanoes" in the Ross Slide Sheet, a submarine landslide block, at the type locality of the Ross Sandstone Formation, Shannon Group. A $10 \mathrm{~cm}$ scale on the left flank of the mound.
Fig. 2: A contact between the Shannon Group and Central Clare Group at Point of Relief, north of Ross. Slump sediments of the uppermost part of the Gull Island Formation, Shannon Group (lower) are overlain by prodelta sediments of the basal Tullig Cyclothem, Central Clare Group (upper).

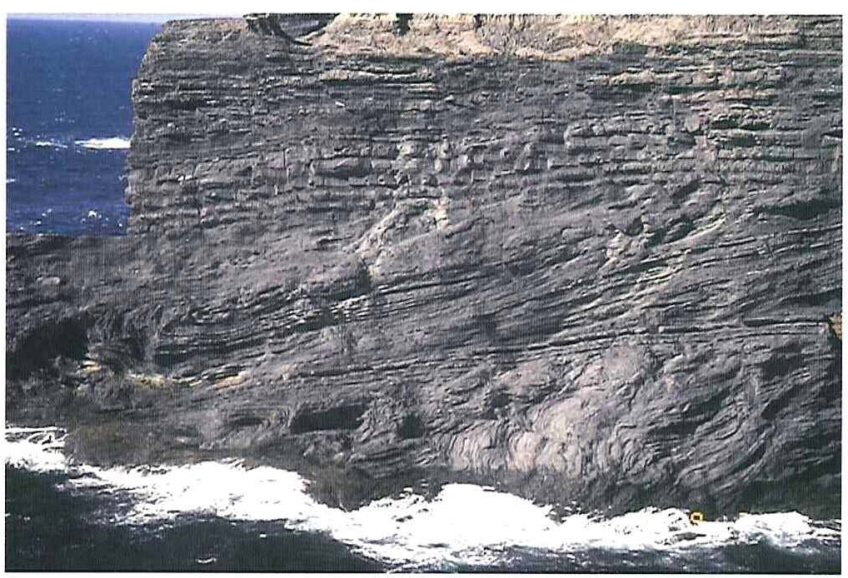

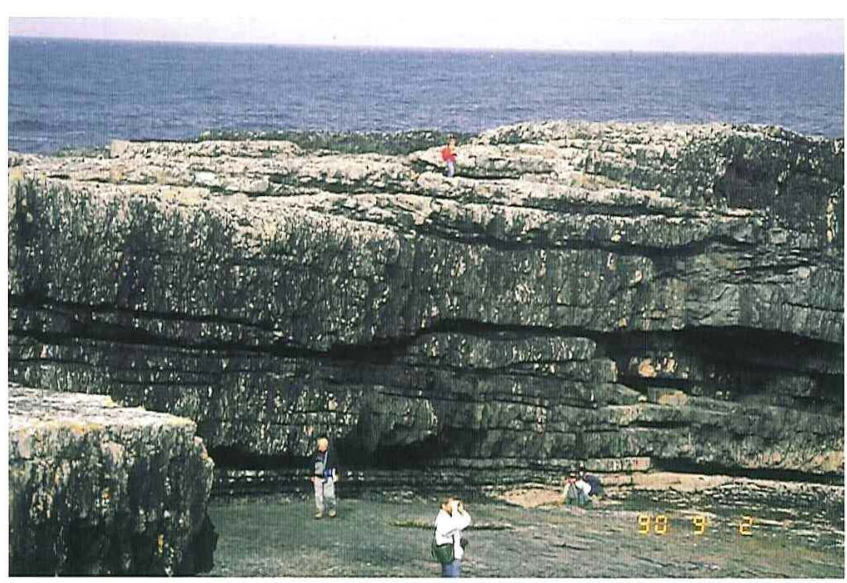

Fig. 3: Thick-bedded turbidite sandstones of the Ross Sandstone Formation, Shannon Group. Renowned R. Walker is wondering on the top of the outcrop.

アイルランド西部，クレア州の石炭系Namur統のタービダイトと沿岸成層

1990年, 第13回国際堆積学会議がイギリス・ノッティンガムで開催された際、クレア州海岸を中心に露出する石炭系の堆積相を見学する 機会を得た. 西ヨーロッパでもっともスペクタクルな海岸である. 案内者はT. Elliottほか.

表紙: Doonbeg北西海岸, Central Clare居群Tullig Cyclothemに発達するHCS砂岩. ただし案内者はmouth bar堆積物と解釈し現地でか なりの議論をまねいた. 写真 1 : Shannon層群Ross Sandstone層の模式地に見られる, Ross Slide Sheetと呼ばれる海底地滑りブロック 内の細粒砂火山. 火山左斜面に $10 \mathrm{~cm}$ のスケール. 写真 2 : Ross北方, Pt. of Reliefの露頭. 下部はShannon層群Gull Island居最上部のス ランプ堆積物. 上部はCentral Clare居群Tullig Cyclothem基底のプロデルタ堆積物. 写真 3 : Shannon層群Ross Sandstone層の厚層ター ビダイト砂岩. 露頭の上を歩いているのはR. Walker氏. (立石雅昭, 新潟大学理学部) 